\title{
教育講演・基礎漢方講座
}

\author{
私の漢方医学の習得： \\ 漢方の魅力にとりつかれた外科医のあゆみ
}

千福 貞博

センプククリニック，大阪， $=530-0047$ 大阪市北区西天満4-6-14

\section{How I Learn Kampo Medicine : The Learning Process of An Ex-surgeon who has been Charmed by Kampo}

\author{
Sadahiro SEMPUKU
}

SEMPUKU Clinic, 4-6-14 Nishitenma, Kita-ku, Osaka 530-0047, Japan

\begin{abstract}
I have been an ordinary surgeon. But, for about eight years, I have frequently been prescribing Kampo drugs. So, at first, I'd like to tell my story about how to learn Kampo and how to improve my Kampo skill. In this part, I introduce my interesting career, my character and my favorite Kampo books and masters (lecturers). Then, in my experience, I try to clear the property of Kampo, and show the key points of the Kampo therapy. At last, I refer to my attitude of the daily Kampo therapy.

Key words : how to learn Kampo, key point of Kampo therapy

\section{要旨}

私は，普通の外科医でした。ところが，約 8 年前から漢方薬を非常によく使うようになっています。そこで，は じめに，私がゼのようにして漢方を学び，漢方の技量を修練していったかを話したいと思います。この部分では， 私のおもしろい経歴や性格, 私の好きな本, 漢方の名人（講師）を紹介します。それから, 私の経験から漢方の特 性を明らかにし，漢方治療の要点をお示しします。最後に日常の漢方治療における私の心がけを話します。
\end{abstract}

キーワード : 漢方学習法, 漢方治療の要点

\section{はじめに}

皆さん，こんにちは。私の講演は，この漢方基礎 講座の中で，最も初歩レベルのものだと思います。 どうかコーヒーブレイクのつもりで, 居眠りしなが らでも結構ですので聞いてください。

今日の話ですが，五つのセクションに分けてお話 ししたいと思います。(1)自己紹介をしたいと思いま す。すなわち, 漢方を取り入れた本当の理由, 表題 に私は外科医とありますが，なぜ漢方を使うように なったかということです。(2)自己分析から思う漢方 医向きの性格。今は，ものすごくたくさんの漢方を 使うような医者になっていますが，それをちょっと 自己分析してみて，どうしてなのだろうということ を括ししたいと思います。(3)私の尊敬する先生。 実は私は，こんなところでしゃべるよりは，どちら かというと，皆さんと同じょうにそちらに座って偉 い先生の話を聞きたい方です。私が今まで聞いた中
で，いい先生のお話，それから，そのエッセンスを ちょっとお話ししたいと思います。(4)使ってみて思 う漢方の特徵。(5)最後は, 漢方を使うときの私なり の心がけについてお話ししたいと思います。

\section{1. 自己紹介}

私は高柣にあります大阪医科大学を昭和 58 年に卒 業しております。一般・消化器外科というところに 入局しました。当時の教授は岡島邦雄と申しまして, 外科をされている先生方だったら，ょくご存知と思 います。胃癌の手術をしますと天下一品の先生です。 16番といいまして, 大動脈周囲のリンパ節郭清を あっという間にしてしまわれる先生でした。すごい 先生ですが，この先生が東洋医学をやっているわけ ではなく, 本格的な漢方教育は一切受けたことはあ りません。風邪に葛根湯を使う程度の医者でした。

実は開業を 8 年前に致しまして, 初めて本格的に 漢方を使うようになって抢ります（図１）。これは 
私どものセンプククリニックの玄関です。ここ，国 際会議場から歩いて30分ぐらいの北区内にあります。 さっきは外科医だと言っていたのに，内科，アレル ギー科, 循環器科, 心療内科，この標榜科は「うそ」 ではないかということですが，実はこれにはわけが ありまして，この標榜科をつけて，センプククリニ ックを開業したのは，私の妻であります。

ある晚のことですが，私の妻が「ちょっとパパ， 実は産業医にスカウトされた」と。「それはよかっ たね」と。「ところで，センプククリニックはどう するの」という話になったのです。ピロートークで す。「パパがしたらいいやん」と。私はその時は高 梘赤十字病院の外科の医者でした。ということは「病 院を辞めてここへ来いということやな」ということ になりました。で，急きょ，部長先生，教授に頭を 下げて辞めさせてもらいまして，このセンプククリ ニックを継ぐことになりました。

漢方を使い始めた本当の理由ですが，このセンプ ククリニック，今，申しましたように妻が先に開業 したわけで，実は漢方を残してくれました。女房は 私と同級生で大阪医科大学出身です。学生時代に東 洋医学研究会（東医研）に入っていましたので, ちょっとは漢方のことを知っていたのです。残って いた漢方薬がここに書いてあります15種類です。こ れを漢字にしますと，やたら長くなりますので，番 号で書きました。

1 番はご存じかもしれません, 葛根湯， 3 番：乙 字湯，それから 7 番：八味地黄丸，8番：大柴胡湯， 9 番：小柴胡湯, 12 番：柴胡加竜骨生蚛湯， 14 番： 半夏瀉心湯, 23 番: 当帰药薬散, 24 番: 加味逍遙 散，41番これから夏バテでよく使われるかもしれま せんが補中益気湯，48番：十全大補湯，61番：桃核 承気湯，96番：柴朴湯，114番：柴苓湯，126番：麻 子仁丸，この15種類でした。

私は外科医でしたので，こんな漢方には，全く興 味がなかったので，「これは使い終わったら，もう 二度と注文するなよ」と事務の者にも言っていたの です。ただ，放ったのではもったいないので，本で 少しだけ勉強をして終わりにしようと思っておりま した。

私のクリニックの近くに旭屋本店という大きな本 屋さんがありまして，そこで 2 冊の本を見つけまし た。一つは『漢方診療のレッスン』という花輪先生

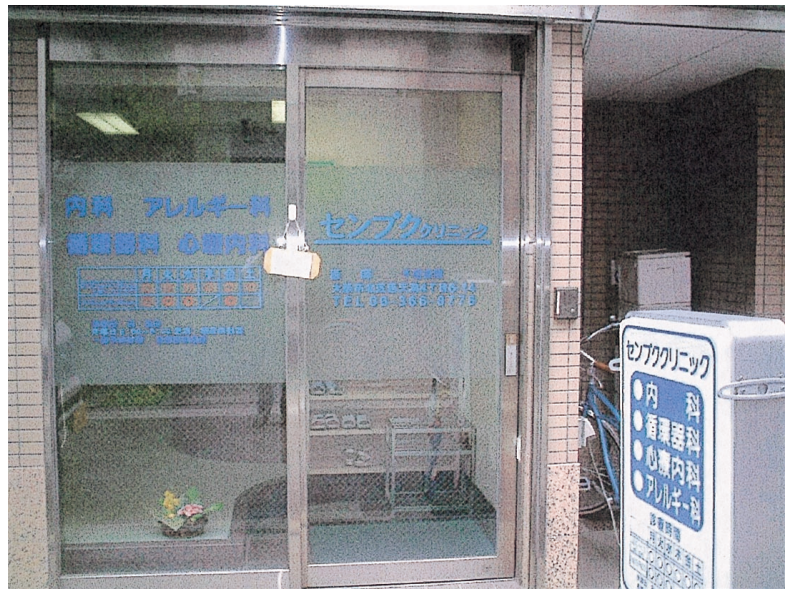

図 1 センプククリニック玄関 標榜科は，これでいいの?

がお書きになった本。もう一つは『和漢診療学』, これは寺澤先生のお書きになった本です。この 2 冊 の本を，当時は暇でしたので，徹底的に読むことに なったわけです。今，考えてみますと，妻とこの 2 冊の本がなかったら, 漢方を使っていたかどうか分 からないと思います。

寺澤先生には申し訳ないのですが，私はこの『漢 方診療のレッスン』を先に読みました。この会場の 中にも西洋医学の方から，これから漢方を使㧍うと 思っていらっしゃる先生が扔られると思います。こ の場合は，是非，花輪先生の本から，先に抢読みに なることをお薦めします。

この花輪先生の本の前半部分まで読んで，どんな ことを感じたかということですが，一つは漢方とい うものは，病名にこだわるよりも，症状や所見にこ だわって使うのだという解釈に至りました。先ほど 申しましたように，風邪は葛根湯という使い方をし ておりましたが，これだけではだめなのです。症状 でいろいろ，実は風邪薬は漢方の中にはご存じのよ うにたくさんあるわけです。使い分けないといけな い。

もう一つ，私がよく使っていたのは，慢性肝炎に 小柴胡湯という使い方をしていたのですが，こうい う 1 対 1 対応をしてはだめなのだということが分か りました。

そしてもう一つは腹証，先ほど三㵔先生が解説さ れていましたが，腹証というのがどうやら大切なも ののようであることに気がつきました。西洋医学的 に私は腹部外科医でしたから, 理学的所見 $=$ 身体所 見を見るついでに，漢方の腹診というものをやって 


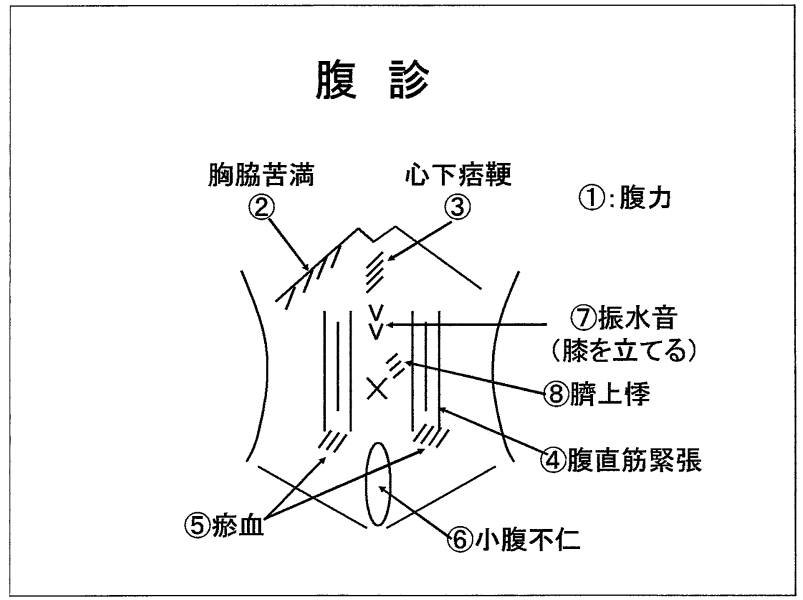

図 2 カルテに日常記載している腹診所見

みようということにしました。

本だけでは少し物足りませんでしたので，ツムラ の講演の講習会，これは本当にたくさんありますが， それの一つに出席しました。内容は，今回の学会の セッションでもアトピー性皮膚炎の漢方というのが ありましたが，それだったのです。いま一つ解りま せんでした。ただ，最後に腹診の実習というのがあ りまして，「腹部外科医をやっていたのだからここ れぐらいできるだろう」という気持ちでとにかく挑 戦しました。

その直後に,「腹診というのが結構面白かったよ」 とMRに申しますと, 腹診のビデオを 3 巻も持っ てきてくれました。当時, 患者さんも少なくて暇で したので，ぜんそくの吸入のデモンストレーション 用にビデオデッキを待合いに置いていましたが，そ れで私が，この腹診のビデオを一生懸命見ていまし た。

しかし，どうですか。ここでもう漢方をされてい る先生は当たり前としても，「おなか」を触って， 腹部以外の疾患まで分かるはずがないだろうという 疑いは消えませんでした。とにかく変な医者と思わ れても，何でもいいから「おなか」を触ることにし ました。図 2 が腹診です。先ほどの三㵔先生のスラ イドと，実はほとんど同じなので非常に安心してお ります。腹力を診て, 胸脇苦満, 心下癌鞭, それか ら腹直筋の緊張，疼血，小腹不仁，それから振水音， 臍上悸。振水音の時には，私は膝を立てたほうが， 音が出しやすいように思っていますので，いつもこ れを気にしております。昨日の基礎医学講座の中で, 中医学の大野先生によりますと,「中医では腹部は,

\section{腹 証 私が診ている8つのポイント}

(1) 腹カ 5つに分けるか 2つに分けるか (強か弱)

(2) 胸脇苦満

これがあると思えば「柴胡」から選ぶ

(3) 心下㾂鞕

(14) 半夏㵻心湯、113)三黄瀉心湯、15) 黄連解毒湯

(4) 腹直筋の緊張

(5) 瘀血 これがあると思えば「苟薬」から選ぶ

駆瘀血剂を使う

(6) 小腹不仁 $\rightarrow$ とにかく(7)八味地黄丸を使ってみる

(7) 振水音 水毒 (水滞) と考える

(8) 臍上悸 イライラしている 眠れない $\rightarrow$ 西洋薬でも可能

膝を曲げて診る」と言われていました。それは，西 洋医学と同じだということなので，その辺はちょっ と日本漢方と違うのかなと思っています。

私が診ている八つのポイントを文章にします

3 )。腹力ですが，私は大体五つに分けて 5 分の幾 つというふうに記載しております。二つに分けてお られる先生もいるかと思います。胸脇苦満です。こ れがあると思えば，柴胡剂から選んでいます。心下 㾂鞭の時に，14番：半夏瀉心湯は私の頻用処方の一 つで，非常に好きです。先ほど三渚先生が中脘のと ころの痛みというか㾂鞭のことを言われていました が，その時には私は喜んでこの14番を使うようにし ています。あとは三黄瀉心湯, 便の性状で三黄瀉心 湯を使ったり，あるいは，ものすごくイライラして いる人には，黄連解毒湯を使ったりすることもあり ます。

腹直筋の緊張，三㵔先生と全く一緒で，これがあ ると思えば药薬の入っている方剤の中から選んでい ます。瘂血ですが，駆疠血剤を使うというふうにし ております。小腹不仁は，もうとにかく八味地黄丸 を初めに使うようにしています。牛車腎気丸という デラックス版もありますが，八味地黄丸をまず私は 使っています。振水音は, 後で詳しく述べますが, 水毒, 水滞と考えて, 水毒のお薬, 特に五苓散を使 います。

三潴先生と全く同じなので非常にうれしいのです が，臍上悸を見たら，イライラしている，眠れない。 先生が扔っしゃったように，私もこの臍上悸がある 人というのは，途中覚醒のパターンだろうと思って います。ですから，どちらかというと，ちょっとデ 


\section{症例1 49歳、男性、建築業役員}

主 訴：何ごとでもものを亜いように考える。 イライラする。手指の振戦

現病歴: $(X-2)$ 年前から胃部不快感があり、内視鏡検査を受けた。 良性であったが、癌に対する不安がとれなかった。 精神科(前医)にて、抑うつ型神経症の診断を受け、 安定剂と抗うつ剤を処方された。 都合で、X年秋から当科を受診。 前医の処方と自律訓練法などを行ない軽快した。 しかし、また症状增悪、手指に振戦も出現したため、 再度来院された。

図 4 症例 1

八味地黄丸が有効であった抑うつ型神経症の一例

プレッションの人かなと考えています。この臍上悸 に関しては，ここに書いていますが，何も漢方で柴 胡加竜骨牡蚛湯とか, 桂枝加竜骨牡蚛湯, 抑肝散加 陳皮半夏だけを選ぶのではなしに，今，はやりの SSRI であるとか, ベンゾジアゼピン系の精神薬を 使うようにしております。

とにかく腹証というものを信じまして, 私は漢方 を使いました。もう皆さんもここに抢られる人はビ ギナーズ・ラックを経験されていると思うのですが, 私にはこのビギナーズ・ラックがあまりにも印象的 でしたので，これはちょっと小さなところに症例と して報告いたしました。「八味地黄丸が有効であっ た抑うつ型神経症の一例」です。

49歳の男性で建築業の役員をされていらっしゃい ます（図４）。主訴は何事でも，ものを悪いように 考える。いらいらする。手指に振戦（tremor）があ るということです。現病歴ですが， 2 年前から胃部 不快感がありまして，内視鏡検査を受けられました。 benign（良性）だったのですが，癌に対する不安が 取れませんでした。精神科, 前のドクターのところ で抑うつ型神経症の診断を受けられまして, 安定剤 と抗うつ剤を処方されておられます。都合で秋から 当科を受診となって，前医の処方を引き継いで，あ とは㗇でしたので，自律訓練法，ご存知の方がある かもしれません, AT といいまして, 腕が重い, 腕 が温かいなんていうのも暇でしたので，やっており ました。

これをやっていますと，軽快しました。しかし， また症状が増悪していきました。手指に tremor も 出現したため, 再度, 来院されています。
現 症: 身長 $176 \mathrm{~cm}$ 、体重 $89.8 \mathrm{~kg}$ 、血圧 $132 / 82 \mathrm{mmHg}$

血液·生化学的所見: 特記すべきことなし

（糖尿病、甲状腺機能異常なし）

漢方医学的所見:脈、舌に異常なし 腹部: 下腹正中に著しい腹壁トーヌスの低下 (小腹不仁)を認めた。他に腹部に所見なし。

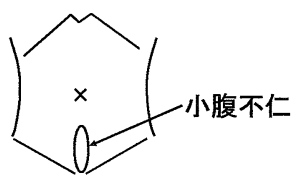

図 5 症例 1 の現症と漢方医学的所見

現症です（図 5 )。身長 $176 \mathrm{~cm}$, 体重 $89.8 \mathrm{~kg}$, 血 圧が132/82, 血圧は正常ですが，かなり大柄のかた です。血液，生化学的所見に特記すべきことはあり ません。私ももともと西洋の医者ですから, tremor ということでこういう人だったら hyperthyroidism （甲状腺機能克進症）がないだろうかということを チェックしましたが，異常はありませんでした。

漢方医学的所見に, 脈, 舌に異常なしと書いてあ ります。私はカルテに堂々と書くようにしているの ですが，初めからこんなのは分かりっこないと思う のです。三潴先生も脈診，あるいは三谷先生が舌診 の講義をされましたが，何でも初めから分かるもの ではないと思うのです。たた，堂々とカルテに記載 しておくと，あとで役に立つかなと思っています。

腹部です。腹診所見で, 下腹正中に著しい腹壁 トーヌスの低下，小腹不仁を見つけました。ほかに 腹部に所見なし。これも，未熟な頃なので「うそ」 かもしれません。

経過です。ツムラの八味地黄丸エキス顆粒, $7.5 \mathrm{~g}$, 要するに 3 袋分 3 で開始しました。 1 週間後には, まず精神状態が著明に改善し, 手指の振戦も軽度改 善。以後, 約 3 力月服用され, 廃薬ということに なったのです。

漢方で面白いなと思うのは，この症例で，まず精 神状態が改善しました。おなかを触っただけなのに， なぜ精神状態が改善するのか。しかも，今考えても 不思議ですが，八味地黄丸というと，どちらかとい うと tremor が誘発されそうな附子が入っているの です。それが治ってしまう。それともう一点，何と いっても漢方の面白さは，この人は勝手に止めてし 
まっているのです。廃薬なのです。これは私でも， 今だったらもちろん漢方も使うかもしれませんが, SSRI を一緒に入れるとか，それからべンゾジアゼ ピン系を使っていると思うのですが，そうして治し て3カ月で，果たしてこんなにうまいことコンプ リートに治すことができただろうかということを考 えております。

今，この患者さんは患者さんとしてではなく，当 院へ本当に暇なときに遊びに来ます。一緒にゴルフ などをして遊ぶ関係になっておりますが, 症状の再 発は一切ありません。

自分の頭の中での，この症例での考察です。この 症例で感激したことは, 腹診は腹部疾患の所見を見 ているのではないということです。漢方をするとき には，虚心坦懐ということです。別の言葉で言いま すと, とにかく先入観を捨てて, 温故知新, 古きを 温め新しきを知ると，ばかにせずに古きを温めてみ ようということです。

信じられないことですが，とにかく漢方がこのと きぐらいから面白く感じられました。風邪には自分 では，昔は抗生剂を必ず飲んでいたのですが，抗生 凨も飲まずに試してみることにし，その後，患者さ んには，葛根湯加川芦辛夷，小柴胡湯，小青竜湯， 麻黄附子細辛湯, 私はこれが大好きですが, 補中益 気湯，それから桔梗湯といったものを多用するよう になっています。ただし，患者さんには，抗生剤と 併用しております。

昨日，この会場におられた人で, 田代先生の講演 を聞かれている人は，おわかりと思いますが，実は 抗生剤の併用は, 「資化菌」という腸内細菌が死ぬ から，漢方を使う治療には本当は不利のようなので す。昨日，勉強になりました。

\section{2 . 自己分析から思う漢方医向きの性格}

なぜこんなに漢方が好きになったかということで す。ここも五つに分けて考えてみました。西洋医学 的研究をしたことのある人は向いていると思います。 私も研究をしました。どんな疾患にも手を出そうと する開業医向きの性格。心身医学的アプローチも大 切だと思っている人。診断よりも治療が好きな人。 そして最後に，これがいちばん大事なのかもしれま せんが，好奇心が強い，頭がソフトでなかったらだ めだと思います。

まず西洋医学的研究をしたことがあるかどうかと
いうことですが, 西洋医学の研究は, ややもします と, 病気, 病態, 薬理作用などの解明に終始します。 結局，目の前にいる患者さんを治すということから は，ちょっと分離してしまうのです。学位論文など を書いたことのある人は, 自分の研究の限界も知っ ています。生意気かもしれませんが，実際の医療で は, 西洋医学は科学武装をしている割に大したこと はないと思っている人に向いていると思います。

ただ，学位論文は大事だと思います。この会の会 頭であります大澤先生は, 私の学位論文の副査なの で，決して学位論文が無䭾だとは申しておりません。

また実験は, 思いがけない結果を大切にする観察 眼が必要です。これは実験をされたことのある人は 分かると思うのですが, 動物実験のデー夕などを見 ていますと，当初の思惑どおりにはいかないのです。 自分の実験は失敗かなと思っていますと, あとで データ整理とか, ほかの論文を読んでいますと，「な るほどそういう理由で，こうだったのか」というこ とに思い至ることがあります。

漢方を使っていますと, 思いがけない好結果が患 者さんに出ていることが多いのです。それが，また 次に使ってみようという動機になります。ちょっと 生意気ですが，ウィリアム・オスラーという有名な 内科の先生の “Listen to the patient, he is telling you the diagnosis.” (患者さんの言うことを聞きなさい, あなたに，もう診断を告げていますよ）という言葉 は，洋の東西を問わないような気が致します。

次に，どんな疾患にも手を出そうとする，いわゆ る general practitionerタイプの人がいいのではない かと思っています。しかも，難病もやってやろうと いう人がいいと思います。漢方の楽しさですが，こ れはこれまでに治せなかった疾患に対して, 全く 違った方法で攻撃ができるということです。たとえ 病気に勝てなかったとしても，技が多ければチャン スは増えます。患者さんには，少なくとも余裕のあ る医者と見えます。よくうちも近くの大きな病院か ら，研修医の方が来られるのですが，「これは言う なよ」といつも言っていることがあります。それは， 「治りません」と患者さんに面と向かって言うこと です。少なくとも漢方を知っていますと，これは言 えなくなります。時間稼ぎにはもってこいであると 思っています。

それから, 心身医学的アプローチも大切だと思っ 


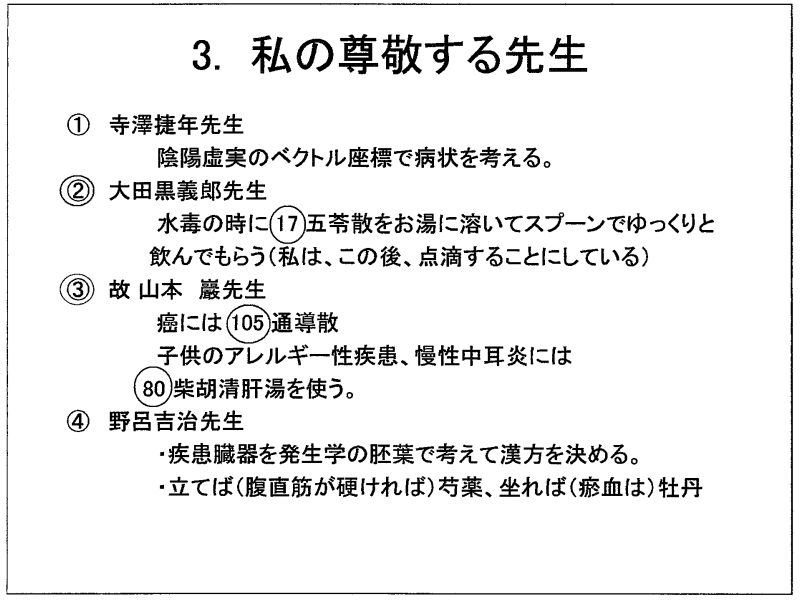

図 6 私の尊敬する先生（その 1$)$

ている人に向いていると思います。漢方と西洋薬郕 との大きな違いは，すべての漢方に精神科薬剂が配 合されていると思って間違いないと思っています。 逆に言えば「心身一如」の「身」，ボディーのほう だけ治しても全体は治らないはずです。私は，眠く なったり，ふらついたりがなければ，精神科薬の使 用を大切だと思っています。大学時代からドグマ チールであるとか，セディールは最近の薬ですが, リーゼ，このあたりをよく使っていました。しかし， これらの薬の使用頻度は，漢方を使うようになって から減っております。

また，診断よりも治療が好きという先生に向いて いると思います。要するに金もうけよりも，患者さ んが好きなドクターに向いていると思います。私も 訪問医療とかやっておりますが，あるいは北区医師 会の理事なんかもやっています。こういうことを進 んでやるような先生なら，一度はまると，もうどん どん使い出すと思います。漢方は完全に治せなくて も，QOL（quality of life）をものすごく上げていく ものだと信じております。

そして最後に，漢方医向きかどうかということで すが，好奇心が強くないとだめだと思いますし，頭 が柔らかくないとだめだと思うのです。唯物論, 私 たちは中学, 高校, 大学と, 分子, 原子, 解剖, 生 理, 生化学, こういった化学式などにならされてき ました。しかし，これだけが正しくて，「なぜ今更， 気血水だ」とか，「なぜ肝が充ぶったら怒るという 意味になるのだ」と，こういうことを考えている人 はだめだと思うのです。

「そういえば，別に俺も分子や原子を見たわけで
(5) 広瀬滋之先生

広瀬先生そのものから気」をもらいに行く。

講義そのものが気剂。

(6) 檜山幸孝先生

・ツムラの1)から 40ぐらいまでをよく勉強する。

生薬の少ないsimpleな処方は、速効性だが耐性ができること がある。

(7) 江部洋一郎先生

·黄耆と人参では益気する方法がちがう。

人参は守胃してから気を高め、黄耆は今ある気をめぐらせる。

(8) 三谷和男先生

(9) 峯 尚志先生\}わからないことは、この2人に何でも聞いてみる。

図 7 私の尊敬する先生（その 2 )

はないけれど」とか，あるいは「空に穴が開いて， 光の漏れてくるのが星だそうだ。そう言われれば, 「それはそうかもしれないな」と,こうやって今もっ て思っていそうな人に向いていると思います。

\section{3．私の尊敬する先生}

先ほど申しましたように,私は,こうして前に立っ て話をするより，そちらに座って話を聞くほうが非 常に好きなのです（図 6，図７）。トップバッター に寺澤先生を挙げさせていただきました。この先生 が私を恐らく，漢方好きにさせた第一人者ではない かと思っています。一昨日も昖会いしましたら，覚 えていてくださいまして, 握手をしてくださいまし た。非常に感激しております。この先生は陰陽，虚 実のベクトル座標で病状を考えて，お薬を使われま す。このことについては, 最初に 2 冊の本を紹介い たしましたが, 医学書院のほうの『和漢診療学』の ほうを涜みになると，非常に分かりやすいかと思 います。

2 番目, 大田黒先生です。この先生は私の先輩, 大阪医科大学のご出身でいらっしゃいます。水毒の ときに五苓散をお湯に溶いてスプーンでゆっくり飲 んでもらうということを扔しゃいました。私はこ のあとに点滴をすることにしています。あとで症例 を少しお出ししたいと思います。

3 番目, 亡くなられました山本巌先生, この先生 は癌には通導散と仰られています。皆さん, どうで しょう。よくいろいろなところで聞きますと, 癌と いいますと補剤です。補中益気湯とか，あるいは十 全大補湯がいいと扮聞きになっていると思いますが, この先生は逆に瀉法, 通導散がいいとおっしゃって 
います。また，子供のアレルギー性疾患，慢性中耳 炎には柴胡清肝湯を使うと，これはあとで症例を出 します。

4 番目，野呂先生です。残念ですが，この先生は 大阪の住吉で開業されておられましたが，昨年でし たか，引退されて，あまり講演活動などは，もうさ れないということです。この先生に教えていただい た中には, 疾患臟器を発生学の胚葉で考えて漢方を 決める。例えば生薬の麻黄というのは全部, 痛み(神 経）であるとか，あるいは皮膚がゾーッとするとか， そういった外胚葉のお薬なのだよというふうに，生 薬を胚葉で分類して，効果を分けて考えていく。こ れは非常に面白い発想です。

それからて談でおっしゃってくださいましたが， 立てば菏薬，座れば牡丹，腹直筋が固くて立ってい れば药薬，下のほうに座って疙血があったら牡丹を 使うのだよという話もしてくださいました。

広瀬先生，もうこの先生をご存じの先生は，その とおりだねと扔っしゃると思いますが，この先生そ のものが「気」なのです。「気」をもらいに行きま す。私はちょっと診療に疲れていると，広瀬先生の 講演会を探して聞きに行って，元気になるようにし ています。お話は寺澤先生と同じような気血水を中 心としたような解りやすい括話です。

檜山先生です。この先生は, 寺澤先生のお弟子さ んです。ツムラでなくてもどこでもいいのですが漢 方の番号の,「1番から40番ぐらいまで，よく勉強 したらいい」と教えてくださいました。なぜかとい うと, 製薬会社も商業ベースですから，やはり使用 頻度の高いほうから， よく売れるものから前に出し ているはずです。つまり，葛根湯から猪苓湯ぐらい まで，しっかり勉強しなさいと言われました。そう なると，補中益気湯がちょうど41番でかわいそうな ので，私は41番まで勉強したらいいのではないかな と，いっも思っています。

この先生の解説で解りやすくて非常に意味深いな と思ったのは，「生薬の少ないシンプルな処方は, 速効性だが耐性ができることがある」ということで す。これはそのとおりだと，私も自分で使っていて 思います。大黄甘草湯という薬があり，大黄と甘草 だけの二味です。下剤としての使用はものすごく便 利ですが，これをずっと使っていると西洋薬と同じ ように，耐性ができて，お通じが来なくなるのです。
それと药薬甘草湯でもやはりそうです。药薬甘草湯 だけで，こむら返りを治していますと，なぜか知ら ないのですが，だんだん効果が弱くなっていくよう な気がいたします。

江部洋一郎先生です。この先生は, 京都の方の先 生ですが，この先生の講演は中級クラス以上だと 思っています。今でも，この言葉が分かるような， 分かっていないような気がします。どういうことを おっしゃるかというと, 黄者と人參では益気する方 法が違う。「人參は守胃してから気を高め, 黄者は 今ある気を巡らせる」。これがパッと分かる人は申 し訳ないですが，私の講演は聞く意味がないかなと 思います。私にはまだ難しいかもしれません。

8 番目， 9 番目，もうこれらの先生はこの学会中, よく皆さんが昖会いになっていると思います。三谷 先生，峯先生，私と大体同じ年齢なので，この 2 人 に何でも聞くようにしています。つまり，この 2 人 が，ものすごく気が優しくて，何でも答えてくれる ので，私の漢方が進歩していったのではないかなと 思っています。

さて， 2 番目に説明しました大田黒先生の方法で す。それを説明する前にもう一回，水毒の復習をし て拉きましょう。三谷先生が今日，朝一番にこの会 場の講義でおっしゃいました舌診のところで, 舌の 歯痕, 歯形がつく。要するに舌が腫大している。そ れから 2 番目, 腹診の方では, 膝を立てておなかを ポンポンポンとたたいて, チャプチャプという音, 振水音です。先ほどの三潴先生の講義のところです。

舌の所見です（図 8 )。歯痕舌です。こういうふ うに歯形が入ります。この写真の方は, 苔もないで す。やはりちょっと腫大しているように思います。 純粋に水毒ではないかなと思っています。

これはちょっと遊びです（図 9)。うちの息子の 舌です。健康なべろかなと思って撮ったのですが, 先ほどの三谷先生の解説でも分かりますが，このあ たりに茸状乳頭が集まってきて，舌尖紅です。少し アトピーがあります。やはり，そうなると柴胡剤を 少し使ったらいいのかなと思うのです。けれども， こいつが飲んでくれるのは小建中湯か黄者建中湯な のです。やはり味を大事にしないといけないかなと， それも考えています。

さて, 大田黒先生の五苓散, 温湯スプーン飲み法 です。使える症例を申し上げます。いちばん効果が 


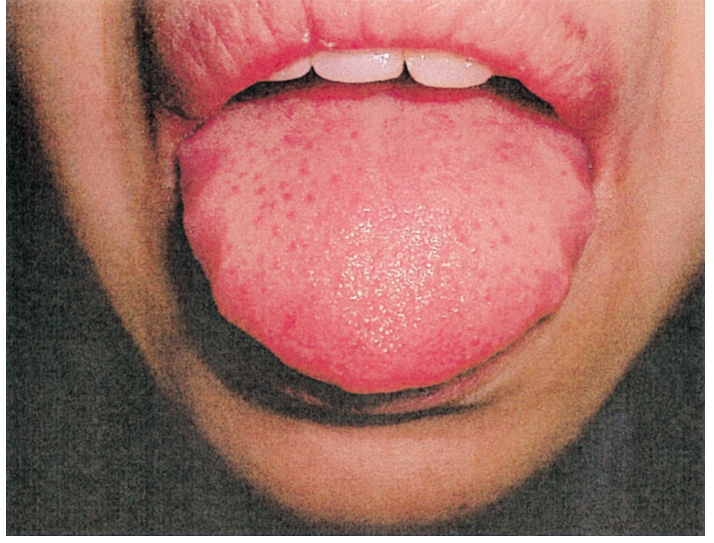

図 8 水毒を考える歯痕舌

はっきり出るなと思うのは, 嘔気・嘔吐のある急性 胃腸炎です。五苓散はそんなにおいしくないのです が，小児にも使えます。その後，私は輸液します。 プリンペランとビタミン B 1の入ったようなものを 入れております。点滴が終わってから, 半夏瀉心湯 か小柴胡湯，これはお湯に溶いても溶かなくても， どちらでもいいと思いますが処方しています。もち ろん14番を使うか 9 番を使うかについては，腹診の 所見で決めたらいいと思います。

それからぜんそく発作です。これも，習ってびっ くりしたのですが, 五苓散をお湯に溶かして, スプー ンでゆっくり飲んでもらってから, 皆さんも $\beta$ stimulant の入った，私は今メプチンをよく使います が，アロテックなどで，ネブライザーをされると思 います。そのあと大体お決まりのようですが，ネ才 フィリンの点滴，半筒ぐらいを入れるのでしょうか, ゆっくり落とさないとこれは危ないですが，そのよ うなものをやります。この後，もうこのごろはやっ ていませんが，麻杏甘石湯を投与します。昔は，麻 杏甘石湯をよく一緒に飲んでもらっていたのですが, 五苓散を飲んでネブライザーをやって，テオフリン を点滴すれば大体，軽快していますので，このレべ ルで終わっています。

このごろ私のクリニックで使用頻度の高いのは, 三番目の migraine（片頭痛）です。このトリプタン 系の薬剤が出たというのは, 片頭痛の患者さんに とっては非常に福音だろうと思うのですが，私のと ころへ片頭痛で「もう先生, 頭が痛い」と言って必 死になって来た場合に，どうするかです。まず五苓 散にいきます。それから，イミグランの点鼻をしま す。10分ぐらい横になっておいてもらいます。10分

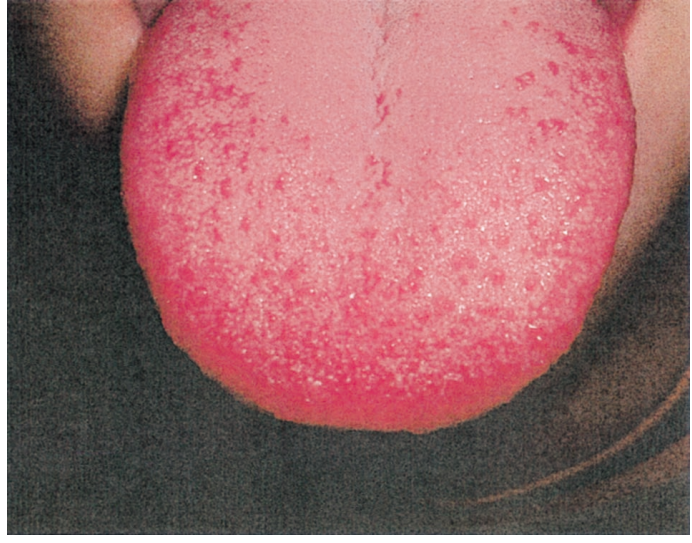

図 9 私の息子の舌, 健康なつもりで撮ったが, 少し舌尖紅。アトピー性皮膚炎あり

ぐらいで軽快いたします。そのあと，この私が飲む と，まずくてしょうがないのですが，呉茱萌湯を一 気飲みしてもらいます。ほぼ九分九厘，これで治っ ていくような気がいたします。

大田黒先生の応用です。他に，お湯に溶かしてよ く使っているのは，急性めまい発作です。本当のメ ニエール症候群ではなくて,「めまい」だけの症状 です。耳鳴り，難聴を伴わない，よく若い女の人が 睡眠不足とかで来られるやつです。確かに, nystagmus（眼振）なんかがちょっと出たりしています。 そのときに39番：苓桂术甘湯と71番：四物湯を混ぜ て，お湯に溶かして飲んでもらいます。もちろん， この後，これがなぜ効くのか，私もまだいまだに知 らないのですが，重曹を静注して，ビタミン入りの 点滴をしています。この急性めまい発作も帰るころ には，かなり軽快しています。

それから，女性の重症生理痛です。これは，68 番: 药薬甘草湯を使います。68番は, 生理痛以外で も，ブスコパンを使う症例だと全部いけると思いま す。胆石発作，尿路結石発作，同じだと思います。 これも，やはりお湯に溶かして服用してもらいます。 そして，ブスコパン入りの点滴を追加します。これ は両者を使って，何もトラブルは発生しませんので， いつも併用しています。これらプラスに内服，ある いは座薬の NSAIDs といったものを使っています。

風邪，インフルエンザの場合です。本当は堂々と 麻黄湯を使ったらいいのですが，そこまで根性がな いので，いつも葛根湯にしています。脈浮の場合は 葛根湯, 脈沈の場合は麻黄附子細辛湯, やはり㧍湯 に溶いて飲んでもらって，点商。あるいは，点滴を している間にインフルエンザが確定していたら，夕 


\section{症例2 5歳、男性}

主 訴：慢性中耳炎あり、耳鼻科に通院するも治らない。

現病歴: (X-1) 年前より耳鼻科にて加療受けるも治らず、 最近は抗生剂を服用すると嘔吐するようになった。 耳鼻科医は、鼓膜切開、排膿ドレナージを勧める も最近は診察も嫌になり、切開の間じっとしていら れないため、その医院ではできないと言われた。 日常生活に問題はないが、聴力の低下も認めら れる。

図10 症例 2 : 小肾難治性中耳炎の一例 （山本巌先生の講義を聴講してから,すぐに患児が来院）

ミフルを使っています。

山本嚴先生のワンポイントレッスンが著効した一 例です。小児の難治性慢性中耳炎の症例です。平成 10年の 9 月23日，大阪のなにわ漢方塾というところ に出席しました。テキストの第 1 ページにこう書い てありました。「私が最初に試みたのが柴胡清肝散 であった。解毒体質の子供は中耳炎, 慢性化膿性中 耳炎になり，悪臭の膿性耳漏，耳だれのため耳鼻科 に通院して難治であり，また一度治癒しても風邪を 引くと再発し, 反復を繰り返す子供に使用した。急 性中耳炎には葛根湯か桔梗石膏でもよくなるが」 云々と書いてありました。

この講演を聞いて，1週間もたたないうちにこ んな患者さんが来ました (図10)。5歳の男性，主 訴，慢性中耳炎あり，耳鼻科に通院するも治らない。 「どこかで聞いたな」というやつです。1 年前より 耳鼻科にて加療を受けるも治らず。最近は抗生剤を 服用すると嘔吐するようになった。耳鼻科医は鼓膜 切開，排膿ドレナージを薦めるも，最近は診察も嫌 になり，切開の間じっとしていられないため，その 医院ではできないと言われた。日常生活に問題はな いが，聴力の低下も認められる。

漢方医学的所見です (図11)。ちょっと進歩して いるのでしょうか，脈・中間と書いてあります。舌 白苔なし。腹部, 右胸脇苦満十, 右臍下に瘀血を認 めています。子供さんでも, さっき三嘟先生が触ら れていましたが，ちゃんと所見が出ます。

経過です。ツムラ柴胡清肝湯を $5 \mathrm{~g}$ です。2 袋分 2 で開始いたしました。1 週間後にお父さんが来院 しました。「とにかく，嫌がらずに服用している」。

\section{漢方医学的所見}

脈:中間 舌:白荅 $(-)$

腹: 右胸脇苦満 $(+)$ 右臍下瘀血 $(+)$

\section{経 過}

(80)ツムラ柴胡清肝湯 5.0g/日 分2で開始した。 1週間後に父が来院。とにかく嫌がらずに服用している。 2力月後に受診。まだ二ボーが見られるとのこと、しかし、来院時よ り元気そうなので、蜨でなかったら服用しておいてと伝える。 4力月後父と母来院。ニボーが消え、聴力が完全に回復したと 礼 に来られる。耳鼻科の先生に、この漢方の話をしたかと聞くと耳鼻 科医に悪いと思って言ってないと。「治れば何でもいいや」と言うと 「そう言われると思ってました」と。

図11 症例 2 の漢方医学的所見と経過（漢方的ラポー ルのおもしろさ)

私はこのフレーズ，味がどうかということを大事に しています。つまり，1 週間後に患者がどう言うか， 嫌がらずに飲んでいるとなると，私はそのまま続投 します。

2 カ月後に受診しました。まだ鼓膜に niveauが 見られるということです。しかし，来院時より元気 そうなので，「嫌でなかったら飲んでおいて」と伝 えました。 4 力月後におとうさんとおかあさんが来 院されました。niveauが消え, 聴力が完全に回復し たとお礼に来られました。

「耳鼻科の先生に，この漢方，柴胡清肝湯を飲ん でいることをお話ししたか」と聞くと，「耳鼻科の 先生に悪いと思って，言っていない」と言われたの です。「治れば何でもいいわ」と私が言うと，「きっ と先生はそう言われると思っていました」。

なぜ症例にここまで書くかといいますと，これが 漢方のラポール (rapport) かなといつも思うのです。 こっちの考えていることを，患者さんも分かってく れている。患者さんの気持ちも，こっちが分かって いる。西洋医学をやっていた時と, 少し違うなと思 うのは,このラポール関係ではないかなといつも 思っています。

\section{4. 使ってみて思う漢方の特徵}

1 番目に, 効果の発現は速い。西洋薬より速いか もしれません（图12）。

2 番目です。大田黒先生の方法ではないですが, お湯に溶かすという方法は非常に速くなって，しか もよく効くと思います。

3 番目ですが，味がまずいと言われたら外れで， 逆に飲めていたら何か御利益があると思っています。 


\section{4. 使つてみて思う漢方の特徴}

(1) 効果の発現は速い。(西洋薬より速いかも)

(2) お湯に溶くと、速くなり、しかもよく効く。

(3) 味がまずいと言われたらはずれ。逆に飲めていたら何か 御 利益がある。

(4) 1週間後に患者さんが何と言うかが決め手である。 (5) 西洋薬がダメな症例の方が良く効くのかも知れない。 (6) (5)のため診療に余裕ができる。これは本当に大きな効果。 (7) 西洋薬との合方は、インターフェロン+柴胡剤以外はもっとと り入れて良いのではないか

(8) 教える先生の話がおもしろい。人物もおもしろい。

図12 使ってみて思う漢方の特徴

ただ，私は，ずっとそう信じてやっていたのですが， 私の後輩，大阪医大の東医研の人たちが下の10階で ポスターをやっていて，味証といろいろな効果を検 討して出しています。私の言っていることと,ちょっ と違うような感じがして，私の立場は悪いのですが， あれを撤去せよとは言いませんので，皆さんも是非， よかったら見てきてあげてください。

4 番目，1 週間後に患者さんが何と言うかが決め 手である。私はそう思っています。効いたよとか, あるいは飲めるよとか，その言葉が大事だと思いま す。

5 番目です。西洋薬がだめな症例のほうが，よく 効くのかもしれないと思っています。この 5 番目の 効果のために, 先ほど言いました「治らない」が言 えなくなるのです。そしてこの 6 番目にある，余裕 ができてきます。これは本当に漢方を使う医者に とっての大きな効果で, 和洋折贵できるという余裕 です。

7 番目，西洋薬との合方，「インターフェロン + 小柴胡湯」だけはちょっとトラブルが発生します。 間質性肺炎の副作用は，もう国家試験にも出るそう ですが，これ以外はもっともっと取り入れたらいい のではないかといつも思っています。

8 番目ですが，教える先生の話が面白いです。人 物も面白いです。今までいろいろな先生の話を聞い てきましたが，とにかく皆さん，面白いと思ってい ます。

\section{5 . 漢方を使うときの私なりの心がけ}

今，私がクリニックで開業していて，どういうふ うに examination しているかということですが, physical を取るときには，漢方を使うかどうか決ま らなくても，漢方と西洋の両方の手技を採るように しています。診断も両方で考えるようにしています。 ですから，先ほど腹診のところで言いましたが，膝 を立てたり伸ばしたり，ちょっとややこしいのです が，それを患者さんに何回もやってもらっています。 腹診は必ずするようにしています。

2 番目，これがものすごく大事だと思うのですが, 西洋病名にとらわれた病名漢方は使わず，症状漢方 や切診を重視する。漢方を使うならば，現代医学は しばし忘れてみられた方がいいと思います。

3 番目，味証を大切にする。味です。必ず，自分 でもその漢方薬の味を知っておかれて, 患者さんが 嫌がれば，これはすぐに撤退されたほうがいいと思 います。ですから，全部一回，お湯に溶かしてやっ ておくほうがいいと思います。2 種類の漢方で悩ん だときに，どうするかです。いちばん手っ取り早い 方法は，私は味証を大事にすると言いましたが，そ の場で患者さんに両方を抢湯に溶かして服用しても らい，味の好きなほうを選んで，こっちにしましょ うと言います。

もし，患者さんが，両方とも味がほとんど同じで， 別に何ら苦にならないとおっしゃったらどうするか ですが，このときは，生薬の少ない構成，檜山先生 が抢っしゃった方法を先に使います。耐性ができる という欠点はあるかもしれませんが，安いし，速効 性が期待できるわけです。

最後に，両方を一緒に使ったらどうなるのだろう。 これを合方といいますが，合方も頭には入れておき ますが，私は最後の手段にするようにしています。

それから，フィードバックをするようにしていま す。漢方の所見，患者さんが治ったよと私に言って くれたときは，先ほど何でもカルテに書いておきま しょうと言いましたが，脈，舌，腹診といった所見 が成功したと考えて，これを自分の武器にしていく ということです。

私は元外科医ですが，アッペ（appendicitis：虫垂 炎）の診断を，McBurneyのところに resistance があ るとか, tenderness だけではなかなかオぺにはなり ませんが, rebound tenderness, Blumberg といろいろ 出てきますとオぺになります。こういったものは, 初めは分からないです。卒業して 3 年目ぐらいまで は，これは切ったらいいのかな，切らないほうがい 
いのか，ものすごく悩んで，上の先生にいろいろ聞 きに行くわけです。それを触っておいて，おなかを 開けます。それで本当に膿んでいる虫垂炎が出てく るか，あるいはカタル，何も実はなかった，といろ いろ経験します。それを繰り返していくことによっ て，この右手が physical examination を覚えていきま す。

漢方も全く同じだと思います。ですから，漢方の 腹診, 脈診, あるいは舌診, それはすべて経験則で いかれるものだと思っていますから，カルテにじゃ んじゃん恥ずかしがらずに，自分しか見ませんから， 書いて扔いたらいいと思います。

うまくいったときに，もう一つだけ私がやってい ることがあります。その治ったということが，その 効果が生薬の構成から納得がいくかということです。 中に入っている人參が効いたのかな，半夏なのかな というふうな，そしてその生薬がどんな働きをする かというのをちょっと勉強します。ここで西洋医学 的な発想を持って，ものを見るということです。

うまくいかなかったときにどうするか。これは素 直に反省します。漢方の所見の取り方がまずかった と反省するか。もう一つは，今までに使ったことの ない漢方の処方なら, 治らないかと考え直してみま す。

今ひとつ大切なことは, 腹診所見はやはり変わり ます。何度でもするということです。それと，今日 私は，気血水でほとんど話をしていますが，六病位，
それから五臓の考えなど発想を切り替えて, ほかの 方法でいけば治らなかったかというふうに考えます。 大変ですが, 『傷寒論』とか, もう一度紐解いて, 古典を読んでみることも必要となる場合があります。

\section{まとめ}

漢方もギャンブルと同じで，一度うまく治って当 たってくれる，いわゆるビギナーズ・ラックを経験 しますと，やめられなくなります。ただ，ギャンブ ルと違いまして, 症状以外に確率を上げる武器があ ります。脈, 舌, 腹診, それから汗, のどの調子, 便の性状を尋㸚ることです。そして，この確率はど んどん上がっていきます。こうなると，いつの間に か西洋薬より，私のように多く使ってしまうのが当 然ではないかなと思っています。とにかく10種類か ら 20 種類の漢方, 私の妻が15種類の漢方を残してく れましたが，それを使い始めてみてもらったらいい かなと思っています。

症状や西洋病名からは証を決めずに, 脈, 舌, 腹 診，特に私は腹診が好きです。腹診の所見を重視し， 漢方薬は漢方の証で使用し, 西洋薬は西洋病名でこ れを併用するということです。こうして，全体の治 療方針を決定することが有用であると思います。こ れは日本の医師の利点と考えています。抄録の予想 でいきますと, 昼からまた, ここの会場で後山先生 がしゃべられますが，このことについて詳しくお話 になられるものと想像しております。 